\title{
Effect of Farm Yard Manure, Gypsum and Nitrogen on Growth and Yield of Rice in Saline Soil of Satkhira District, Bangladesh
}

\author{
A. N. A. Haque ${ }^{1 *}$, M. E. Haque ${ }^{1}$, M. E. Hossain ${ }^{1}$, M. K. Khan ${ }^{1}$ and A. H. M. Razzaque ${ }^{2}$ \\ Soil Science Division ${ }^{1}$ \\ Director General $^{2}$ \\ Bangladesh Institute of Nuclear Agriculture, Mymensingh, Bangladesh \\ Corresponding author : numerybau@gmail.com
}

\begin{abstract}
A field experiment was conducted at the sub-station farm of Bangladesh Institute of Nuclear Agriculture (BINA), Satkhira, to observe the effect of Farm yard manure (FYM), Gypsum and Nitrogen levels on growth and yield of rice (cv. Binadhan-8). The experiment was laid out in a RCBD split-plot design with three replications. Treatments consisted of five FYM and Gypsum combinations in main plot, which were $S_{0}$ : Control, $S_{1}: F Y M 5$ tha $^{-1}+$ Gypsum $140 \mathrm{kgha}^{-1}, S_{2}: F Y M$ 5 tha $^{-1}+$ Gypsum $210 \mathrm{kgha}^{-1}, S_{3}$ : Gypsum $210 \mathrm{kgha}^{-1}$ and $\mathrm{S}_{4}:$ FYM 5 tha ${ }^{-1}$. Four nitrogen levels were assigned in sub-plots viz. $N_{1}: 50 \mathrm{~kg} \mathrm{Nha}{ }^{-1}, N_{2}: 75 \mathrm{~kg} \mathrm{Nha}^{-1}, \mathrm{~N}_{3}: 100 \mathrm{~kg} \mathrm{Nha}^{-1}$ and $\mathrm{N}_{4}: 125 \mathrm{~kg} \mathrm{Nha}^{-1}$. The study revealed that different FYM and Gypsum combinations along with different $N$ levels have significant effect on growth and yield of rice. Mean effect of FYM and Gypsum combinations found the highest for grain (3.69 tha $\left.\mathrm{th}^{1}\right)$ and straw $\left(6.60 \mathrm{tha}^{-1}\right)$ yield where plot received FYM @ 5 tha $^{-1}$ + Gypsum $210 \mathrm{kgha}^{-1}$. Considering the mean effect of different $N$ levels, when the plant received 125 $\mathrm{kg} \mathrm{Nha}{ }^{-1}$ then the maximum grain and straw yield of rice were observed as 3.81 and 6.91tha ${ }^{-1}$, respectively. Due to the interaction effect of both FYM and Gypsum combinations and $N$ levels, the maximum grain yield of rice was found as 4.39 tha ${ }^{-1}$ under the treatment combination of $S_{2} N_{4}$, i.e., FYM @ 5 tha $^{-1}$ and Gypsum $210 \mathrm{kgha}^{-1}$ along with $125 \mathrm{~kg} \mathrm{Nha}^{-1}$.
\end{abstract}

Key words: FYM, Nitrogen, Gypsum, Rice and Saline soil

\section{Introduction}

Bangladesh is a deltaic country with the area of $147,570 \mathrm{~m}^{2}$ in size of which includes more than $30 \%$ of net cultivable land; about $20 \%$ of the total area is covered by the coastal region which is almost 2.85 million hectare, out of this area about 0.83 million hectare lands can be utilized for crop production (Rasel et al., 2013). Salinity is one of the major problems in the agricultural aspects of Bangladesh; it is considered that salinity may generate due to the change in climate and rise of the sea levels especially in the southern area of the country (Ziaul and Zaber, 2013). Salinity creates an adverse environment and hydrological condition that retards crop growth and development and causes reduced yield; it is considered that, the development of soil salinity is caused by two vital reasons, one of them is direct tidal flooding during wet season and another is capillary upward movement of saline ground water during dry season (Haque, 2006). In the past, salinity in the country received very little attention but due to increasing pressure of growing population and demand for more food it has become very important to explore the possibilities of increasing the potentiality of these (saline) lands for sustainable crop production. Saline soils can be made to yield a good crop through proper management practices. In this respect, the development of the most suitable reclamation technology or a combination of technologies is important to optimize farm management and better crop yields. Addition of organic amendments to soil improves soil properties and it is highly accepted by the farmers (Prapagar et al., 2012). Gypsum is the 
most commonly used amendment due to its availability at low cost. Joachim et al. (2007) attributed the beneficial effect of combined use of farm yard manure and Gypsum on the reclamation of sodic soils. Fertilizers containing nitrogen has a significant role in crop production, and both environmental and economic impact (UN-DSD, 2000). Over fertilization with $\mathrm{N}$ may contribute to soil salinization and increase the negative effects of soil salinity on plant performance (Villa-Castorena et al., 2003). This experiment was undertaken to observe the effect of different FYM and Gypsum combinations with nitrogen levels and their interaction on the growth and yield of BINA released rice variety (cv. Binadhan8) under saline soil.

\section{Materials and Methods}

The experiment was conducted at BINA substation farm, Benorpota, Satkhira $\left(22^{\circ} 45^{\prime} \mathrm{N}\right.$ latitude and $89^{\circ} 4^{\prime} 6 \mathrm{E}$ longitude) during the Boro season of 2013 (January to April, 2013). The land belongs to AEZ 13, Ganges Tidal Floodplain and the soil was silty clay in texture, having $\mathrm{pH} 8.0$, total $\mathrm{N} 0.10 \%$, available $\mathrm{P}$ $7.0 \mathrm{mg} \mathrm{kg}{ }^{-1}$, available $\mathrm{K} 0.082 \mathrm{meq} / 100 \mathrm{~g}$ and available $\mathrm{S} 13.5 \mathrm{mg} \mathrm{kg}^{-1}$ (Table 01). The salinity value of initial soil is $6.2 \mathrm{dsm}^{-1}$; this is considered as very slight saline to slight saline soil (SRDI, 2010). The experiment was laid out in a split-plot design with three replications, where five FYM and Gypsum combination treatments were assigned in main plots viz. $\mathrm{S}_{0}$ : Control, $\mathrm{S}_{1}$ : FYM 5 tha $^{-1}+\mathrm{Gypsum}^{-}$ $140 \mathrm{kgha}^{-1}, \mathrm{~S}_{2}$ : FYM $5 \mathrm{tha}^{-1}+$ Gypsum $210 \mathrm{kgha}^{-1}, \mathrm{~S}_{3}$ : Gypsum $210 \mathrm{kgha}^{-1}$ and $\mathrm{S}_{4}$ : FYM 5 tha $^{-1}$ and nitrogen levels were assigned in sub-plots viz. $\mathrm{N}_{1}: 50 \mathrm{~kg} \mathrm{Nha}^{-1}, \mathrm{~N}_{2}: 75 \mathrm{~kg} \mathrm{Nha}^{-1}, \mathrm{~N}_{3}: 100 \mathrm{~kg} \mathrm{Nha}^{-1}$ and $\mathrm{N}_{4}$ : $125 \mathrm{~kg} \mathrm{Nha}^{-1}$. The test rice variety was Binadhan-8, which was released from BINA as a salt tolerant Boro rice which can tolerate $10 \mathrm{dsm}^{-1}$ of EC value (Sinha et al., 2014). Total amount of TSP, MoP and Gypsum were added as broadcast during final land preparation (BARC, 2012). $\mathrm{N}$ fertilizer was applied as urea in three equal splits as i) at three days of transplanting, ii) 28 days of transplanting (tillering stage) and iii) 50 days of transplanting (panicle initiation stage). Intercultural operations were done as when required. The yield parameters - plant height, panicle length, number of plant hill ${ }^{-1}$, number of grains panicle ${ }^{-1}$ and grain and straw yield data were recorded at maturity during rice harvest. The analysis of variance for various crop characters was done following the F-statistics. Mean comparisons of the treatments were made by Duncan Multiple Range Test (DMRT) test.

Table 01. Initial soil status of experimental field at Satkhira, Bangladesh

\begin{tabular}{l|l|l}
\hline Parameter & Test Value & Analytical Methods \\
\hline$\%$ Sand & 8.00 & \\
$\%$ Silt & 55.00 & Hydrometer Method (Black, 1965) \\
$\%$ Clay & 37.00 & \\
Texture & Silty clay & Wet Oxidation (Nelson And Sommers, 1982) \\
$\%$ OM & 1.13 & Glass Electrode Method (Jackson, 1962) \\
pH & 8.00 & EC meter \\
EC & $6.2 \mathrm{dS} / \mathrm{m}$ & Micro-Kjeldahl (Jackson, 1962) \\
$\% \mathrm{~N}$ & 0.10 & Olsen method (Olsen et al. 1954) \\
$\mathrm{P}$ & $7.0 \mathrm{mgkg}^{-1}$ & Flame Photometer (Page et al.,1982) \\
$\% \mathrm{~K}$ & $0.082 \mathrm{meq}^{-100 \mathrm{~g} \text { soil }}$ & Turbidity Method (Page et al.,1982) \\
$\mathrm{S}$ & $13.5 \mathrm{mg} \mathrm{kg}^{-1}$ &
\end{tabular}




\section{Results and Discussion}

\section{Mean effect FYM and Gypsum combinations on growth and yield of rice (cv. Binadhan-8)}

The mean effect of different FYM and Gypsum combinations showed significant resultson plant height, number of effective tiller hill ${ }^{-1}$, number of grains panicle ${ }^{-1}$, grain and straw yield of rice (Table 02). The tallest plant $(105.50 \mathrm{~cm})$ was observed from the treatment $S_{2}$, where the plant received FYM 5 tha $^{-1}+$ Gypsum $210 \mathrm{kgha}^{-1}$ and the shortest plant of $97.00 \mathrm{~cm}$ height was found in control treatment. Similar findings were noted from the study of Abro and Mahar (2007). In case of panicle lengthand number of effective tiller hill ${ }^{-1}$ in rice did not show any significant resultsdue to application of FYM and Gypsum combinations. The number of grains panicle ${ }^{-1}$ was significantly influenced by the application of different FYM and Gypsum combinations. The highest number of grains panicle ${ }^{-1}$ (151.80) were observed in $\mathrm{S}_{2}$ $\left(\right.$ FYM 5 tha $^{-1}+$ Gypsum $210 \mathrm{kgha}^{-1}$ ) treatment, whereas the lowest value of 118.50 grains panicle ${ }^{-1}$ was found in control treatment. Grain and straw yield of Binadhan-8 responded significantly to the application of different FYM and Gypsum combinations in the field before rice transplanting (Table 02). The maximum grain yield $\left(3.69\right.$ tha $\left.^{-1}\right)$ was recorded under the treatment of $\mathrm{S}_{2}\left(\mathrm{FYM} 5\right.$ tha $^{-1}+$ Gypsum 210 $\mathrm{kgha}^{-1}$ ), whereas the minimum yield of 2.82 tha $^{-1}$ was observed in $\mathrm{S}_{0}$ (control) treatment. Regarding the straw yield of rice, similar trends were observed and the highest $\left(6.60\right.$ tha $\left.^{-1}\right)$ and lowest $\left(5.06\right.$ tha $\left.^{-1}\right)$ yield were obtained from the treatment $S_{2}\left(F Y M 5\right.$ tha $^{-1}+$ Gypsum $210 \mathrm{kgha}^{-1}$ ) and $S_{0}$ (control), respectively. From the study of Zakir et al. (1997), it was noted that application of FYM with Gypsum was the best in obtaining highest number of filled grains which might be occurred by the reduction of sodium ion concentration in these treatment over control. Again, use of gypsum and FYM in saline soil may be used as suitable amendment that may reduce the plant injury from the injurious level of salts present in soil (Suriyan et al., 2011) may enhance physiological growth and increased the grain and straw yield of rice.

\section{Mean effect of different levels of Nitrogen on the growth and yield of rice}

Different levels of $\mathrm{N}$ showed a significant result on the growth (plant height, panicle length, number of effective tiller hill ${ }^{-1}$, number of grains panicle ${ }^{-1}$ ) and yield of rice (Table 03). Among the different levels of $\mathrm{N}$, the tallest rice plant of $105.00 \mathrm{~cm}$ was noticed in the plot where $125 \mathrm{~kg} \mathrm{Nha}^{-1}$ was applied and the shortest plant was observed under control plot where only $50 \mathrm{~kg} \mathrm{Nha}^{-1}$ was applied. The increase in plant height due to application of increased level of nitrogen might be associated with stimulating effect of nitrogen levels on various physiological processes including cell division and cell elongation of the plant (Alim, 2012). Due to the application of different levels of $\mathrm{N}$ the panicle length of rice was also varied significantly and the maximum panicle length $(25.48 \mathrm{~cm})$ obtained in $\mathrm{N}_{4}$ treatment $\left(125 \mathrm{~kg} \mathrm{Nha}^{-1}\right)$ which was also statistically similar to $\mathrm{N}_{3}\left(100 \mathrm{~kg} \mathrm{Nha}^{-1}\right)$ with value $24.8 \mathrm{~cm}$ and the minimum panicle length $(23.67 \mathrm{~cm})$ observed by $\mathrm{N}_{1}$ treatment $\left(50 \mathrm{~kg} \mathrm{Nha}^{-1}\right)$. Salahuddin et al. (2009) reported that nitrogen nutrient takes part in panicle formation as well as panicle elongation; as a result, length of panicle increases with the increasing level of nitrogen up to the rate $150 \mathrm{kgha}^{-1}$. In case of number of effective tiller hill ${ }^{-1}$ different levels of nitrogen varied significantly which ranged from 12.57 in $\mathrm{N}_{4}$ treatment to 14.63 in $\mathrm{N}_{1}$ treatment (Table 03). Similar result was found from the research findings of Khan et al. (2010); they stated that the highest number of effective tillers hill ${ }^{-1}$ was produced by high rate of nitrogen and the lowest number of effective tillers hill ${ }^{-1}$ was produced by the low rate of nitrogen. Regarding the number of grains panicle ${ }^{-1}$ in rice there was a marked influence was noticed by the application of different levels of nitrogen. The highest number of grains panicle ${ }^{-1}$ (137.70) was observed in $\mathrm{N}_{4}$ where nitrogen was applied as $125 \mathrm{kgha}^{-1}$ and the lowest (130.50) number was found in $\mathrm{N}_{1}\left(50 \mathrm{~kg} \mathrm{Nha}^{-1}\right)$ treatment. The vegetative growth of the plant was increased by the application of high rate of nitrogen. Carbohydrate assimilation was increased due to the maximum photosynthesis from maximum vegetative growth of the plant. As a result, the number of grain panicle ${ }^{-1}$ was highest due to the high rate of nitrogen (Khan et al., 2010). Results also showed that there was a marked influence on grain yield by the application of different doses of nitrogen. The highest grain yield (3.81 tha $\left.{ }^{-1}\right)$ was observed in $\mathrm{N}_{4}\left(125 \mathrm{~kg} \mathrm{Nha}^{-1}\right)$ which 
was statistically similar to $\mathrm{N}_{3}\left(100 \mathrm{~kg} \mathrm{Nha}^{-1}\right)$ that obtained 3.44 tha $^{-1}$ but the lowest grain yield $\left(2.42 \mathrm{tha}^{-1}\right)$ was obtained from $\mathrm{N}_{1}$ (Table 03). From the study it revealed that yield contributing characters, i.e., panicle length, number of effective tiller hill $^{-1}$, number of grains panicle ${ }^{-1}$ increased with the higher rate of nitrogen application may lead to higher grain yield. Grain yield of rice increases with the increasing $\mathrm{N}$ rate up to a certain level, similar result also reported by Salahuddin et al. (2009).

\section{Interaction effect of FYM and Gypsum combinations and Nitrogen on growth and yield of rice}

From the Table 04, it was observed that the interaction effect of different FYM and Gypsum combinations along with the different levels of nitrogen fertilizer showed a significant result on the growth and yield of rice cultivated in saline soil (Table 04). Among the different treatment combinations, the tallest rice plant of $109.00 \mathrm{~cm}$ was found under the treatment combination of $\mathrm{S}_{2} \mathrm{~N}_{4}$, where nitrogen fertilizer was applied $\left(125 \mathrm{kgha}^{-1}\right)$ along with the Gypsum $\left(210 \mathrm{~kg} \mathrm{ha}^{-1}\right)$ and FYM $\left(5 \mathrm{tha}^{-1}\right)$. The shortest plant of $94.53 \mathrm{~cm}$ was observed as under the treatment combination of $\mathrm{S}_{0} \mathrm{~N}_{1}$. Regarding the panicle length of rice, the interaction effect of different FYM and Gypsum combination and nitrogen levels also showed significant result and the maximum length of rice panicle $(26.33 \mathrm{~cm})$ was found under the treatment combination of $\mathrm{S}_{1} \mathrm{~N}_{4}\left(\right.$ FYM 5 tha $^{-1}+$ Gypsum $140 \mathrm{kgha}^{-1}$ with $\left.125 \mathrm{~kg} \mathrm{Nha}^{-1}\right)$. Hence, the minimum length rice panicle $(12.00 \mathrm{~cm})$ was recorded from the treatment $\mathrm{S}_{4} \mathrm{~N}_{1}$. In case of the number of effective tiller hill ${ }^{-}$ ${ }^{1}$, the value ranged from $12.00 \mathrm{inS}_{4} \mathrm{~N}_{1}$ to 15.60 in $\mathrm{S}_{2} \mathrm{~N}_{4}$ treatment. Considering the number of grains panicle $^{-1}$, highest (155.00) number was found under the treatment combination of $\mathrm{S}_{2} \mathrm{~N}_{4}$ which was statistically identical to $\mathrm{S}_{1} \mathrm{~N}_{4}$ (with value 153.30) but the lowest (112.20) number of grains panicle ${ }^{-1}$ was obtained in $\mathrm{S}_{0} \mathrm{~N}_{1}$ (Control with $50 \mathrm{~kg} \mathrm{Nha}^{-1}$ ) combination (Table 04). Like other parameters, the grain yield of Binadhan-8 rice significantly influenced by the interaction of both FYM and Gypsum combinations and different levels of nitrogen (Figure 01). The maximum grain yield of 4.39 tha $^{-1}$ was obtained from $\mathrm{S}_{2} \mathrm{~N}_{4}\left(\right.$ FYM 5 tha $^{-1}+$ Gypsum $210 \mathrm{kgha}^{-1}$ with $125 \mathrm{~kg} \mathrm{Nha}^{-1}$ ) which was also statistically identical (4.25 tha ${ }^{-1}$ ) to the $\mathrm{S}_{2} \mathrm{~N}_{3}$ treatment and the minimum yield of 1.98 tha $^{-1}$ was found in $\mathrm{S}_{0} \mathrm{~N}_{1}$ (Control with $50 \mathrm{~kg} \mathrm{Nha}^{-1}$ ) treatment. Similarly, the highest and lowest straw yield of rice was noticed as 7.72 and 3.63 tha $^{-1}$ from the treatment combination of $\mathrm{S}_{2} \mathrm{~N}_{4}$ and $\mathrm{S}_{0} \mathrm{~N}_{1}$, respectively (Figure 02).

Table 02. Effect of FYM and Gypsum combinations on yield and yield contributing characters of rice (cv. Binadhan-8)

\begin{tabular}{ccccccc}
\hline $\begin{array}{c}\text { Soil } \\
\text { amendments }\end{array}$ & $\begin{array}{c}\text { Plant } \\
\text { height }(\mathrm{cm})\end{array}$ & $\begin{array}{c}\text { Panicle } \\
\text { length }(\mathrm{cm})\end{array}$ & $\begin{array}{c}\text { No. of effective } \\
\text { tiller hill }^{-1}\end{array}$ & $\begin{array}{c}\text { No. of grain } \\
\text { panicle }^{-1}\end{array}$ & $\begin{array}{c}\text { Grain yield } \\
\left(\text { tha }^{-1}\right)\end{array}$ & $\begin{array}{c}\text { Straw yield } \\
\left(\text { tha }^{-1}\right)\end{array}$ \\
\hline $\mathrm{S}_{0}$ & $97.00 \mathrm{~b}$ & 24.82 & 13.02 & $118.50 \mathrm{~d}$ & $2.82 \mathrm{~d}$ & $5.06 \mathrm{e}$ \\
$\mathrm{S}_{1}$ & $103.10 \mathrm{a}$ & 25.15 & 13.77 & $141.70 \mathrm{~b}$ & $3.20 \mathrm{~b}$ & $6.10 \mathrm{~b}$ \\
$\mathrm{~S}_{2}$ & $105.50 \mathrm{a}$ & 24.40 & 13.98 & $151.80 \mathrm{a}$ & $3.69 \mathrm{a}$ & $6.60 \mathrm{a}$ \\
$\mathrm{S}_{3}$ & $103.40 \mathrm{a}$ & 24.65 & 13.42 & $133.30 \mathrm{c}$ & $3.09 \mathrm{bc}$ & $5.88 \mathrm{c}$ \\
$\mathrm{S}_{4}$ & $99.01 \mathrm{~b}$ & 23.82 & 13.23 & $127.00 \mathrm{c}$ & $3.01 \mathrm{c}$ & $5.68 \mathrm{~d}$ \\
\hline $\begin{array}{c}\text { Level of } \\
\text { Significance }\end{array}$ & 0.05 & $N S$ & $N S$ & 0.05 & 0.05 & 0.05 \\
\hline LSD & 2.723 & 1.370 & 1.804 & 6.699 & 0.163 & 0.084 \\
\hline
\end{tabular}

$\mathrm{S}_{0}=$ No amendment, $\mathrm{S}_{3}=$ Gypsum $210 \mathrm{kgha}^{-1}, \mathrm{~S}_{1}=\mathrm{FYM}\left(5 \mathrm{tha}^{\mathrm{1}}\right)+$ Gypsum $14 \mathrm{kgha}^{-1}, \mathrm{~S}_{4}=\mathrm{FYM}\left(5\right.$ tha $\left.^{1}\right), \mathrm{S}_{2}=$ FYM $\left(5\right.$ ha $\left.^{1}\right)+$ Gypsum 210 kgha $^{-1}$ 
Table 03. Effect of nitrogen levels on yield and yield contributing characters of rice (cv. Binadhan-8)

\begin{tabular}{ccccccc}
\hline Nitrogen levels & $\begin{array}{c}\text { Plant } \\
\text { height }(\mathrm{cm})\end{array}$ & $\begin{array}{c}\text { Panicle } \\
\text { length }(\mathrm{cm})\end{array}$ & $\begin{array}{c}\text { No. of effective } \\
\text { tiller hill }^{-1}\end{array}$ & $\begin{array}{c}\text { No. of grain } \\
\text { panicle }^{-1}\end{array}$ & $\begin{array}{c}\text { Grain yield } \\
\left(\text { tha }^{-1}\right)\end{array}$ & $\begin{array}{c}\text { Straw yield } \\
\left(\text { tha }^{-1}\right)\end{array}$ \\
\hline $\mathrm{N}_{1}=50 \mathrm{~kg} \mathrm{Nha}^{-1}$ & $98.20 \mathrm{~d}$ & $23.67 \mathrm{c}$ & $12.57 \mathrm{~b}$ & $130.50 \mathrm{~d}$ & $2.42 \mathrm{c}$ & $4.47 \mathrm{~d}$ \\
$\mathrm{~N}_{2}=75 \mathrm{~kg} \mathrm{Nha}^{-1}$ & $100.80 \mathrm{c}$ & $24.25 \mathrm{bc}$ & $13.23 \mathrm{~b}$ & $133.70 \mathrm{c}$ & $2.97 \mathrm{bc}$ & $5.45 \mathrm{c}$ \\
$\mathrm{N}_{3}=100 \mathrm{~kg} \mathrm{Nha}^{-1}$ & $102.80 \mathrm{~b}$ & $24.87 \mathrm{ab}$ & $13.51 \mathrm{~b}$ & $135.90 \mathrm{~b}$ & $3.44 \mathrm{ab}$ & $6.62 \mathrm{~b}$ \\
$\mathrm{~N}_{4}=125 \mathrm{~kg} \mathrm{Nha}^{-1}$ & $104.70 \mathrm{a}$ & $25.48 \mathrm{a}$ & $14.63 \mathrm{a}$ & $137.70 \mathrm{a}$ & $3.81 \mathrm{a}$ & $6.91 \mathrm{a}$ \\
\hline $\begin{array}{c}\text { Level of } \\
\text { Significance }\end{array}$ & 0.05 & 0.05 & 0.05 & 0.05 & 0.05 & 0.05 \\
\hline LSD & 1.566 & 0.680 & 1.111 & 1.638 & 0.573 & 0.088 \\
\hline
\end{tabular}

Table 04. Interaction effect of FYM and Gypsum combinations and nitrogen on yield contributing characters of rice (cv. Binadhan-8)

\begin{tabular}{|c|c|c|c|c|c|}
\hline $\begin{array}{l}\text { FYM and Gypsum } \\
\text { combination }\end{array}$ & $\begin{array}{l}\text { Nitrogen } \\
\text { levels }\end{array}$ & $\begin{array}{l}\text { Plant height } \\
\text { (cm) }\end{array}$ & $\begin{array}{l}\text { Panicle length } \\
\quad(\mathrm{cm})\end{array}$ & $\begin{array}{l}\text { No. of effective } \\
\text { tiller hill }{ }^{-1}\end{array}$ & $\begin{array}{l}\text { No. of grain } \\
\text { panicle }^{-1}\end{array}$ \\
\hline \multirow{4}{*}{$\mathrm{S}_{0}$} & $\mathrm{~N}_{1}$ & $94.53 \mathrm{~h}$ & 23.60de & $12.27 \mathrm{~b}$ & $112.20 p$ \\
\hline & $\mathrm{N}_{2}$ & $96.83 \mathrm{gh}$ & $24.47 \mathrm{bcd}$ & $13.00 \mathrm{abc}$ & $117.40 \mathrm{o}$ \\
\hline & $\mathrm{N}_{3}$ & $98.47 \mathrm{fgh}$ & $25.4 \mathrm{abc}$ & $13.07 \mathrm{abc}$ & $122.00 n$ \\
\hline & $\mathrm{N}_{4}$ & $98.40 \mathrm{fgh}$ & $25.73 \mathrm{ab}$ & $13.73 \mathrm{abc}$ & $122.40 n$ \\
\hline \multirow{4}{*}{$\mathrm{S}_{1}$} & $\mathrm{~N}_{1}$ & 100.60 efg & $24.40 \mathrm{bcd}$ & $12.67 \mathrm{abc}$ & $137.90 \mathrm{gh}$ \\
\hline & $\mathrm{N}_{2}$ & 101.90def & $24.73 \mathrm{a}-\mathrm{d}$ & $13.80 \mathrm{abc}$ & $140.20 f g$ \\
\hline & $\mathrm{N}_{3}$ & $103.40 \mathrm{cde}$ & $25.13 \mathrm{a}-\mathrm{d}$ & $13.60 \mathrm{abc}$ & $143.20 \mathrm{ef}$ \\
\hline & $\mathrm{N}_{4}$ & $106.50 \mathrm{abc}$ & $26.33 \mathrm{a}$ & $15.00 \mathrm{ab}$ & $145.40 \mathrm{de}$ \\
\hline \multirow{4}{*}{$\mathrm{S}_{2}$} & $\mathrm{~N}_{1}$ & $100.50 \mathrm{efg}$ & $23.87 \mathrm{cde}$ & $13.13 \mathrm{abc}$ & $147.90 \mathrm{~cd}$ \\
\hline & $\mathrm{N}_{2}$ & $105.20 \mathrm{a}-\mathrm{d}$ & $24.20 \mathrm{bcd}$ & $13.00 \mathrm{abc}$ & $150.90 \mathrm{bc}$ \\
\hline & $\mathrm{N}_{3}$ & $107.50 \mathrm{ab}$ & $24.60 \mathrm{a}-\mathrm{d}$ & $14.20 \mathrm{abc}$ & $153.30 \mathrm{ab}$ \\
\hline & $\mathrm{N}_{4}$ & $109.00 \mathrm{a}$ & $24.93 \mathrm{a}-\mathrm{d}$ & $15.60 \mathrm{a}$ & $155.00 \mathrm{a}$ \\
\hline \multirow{4}{*}{$\mathrm{S}_{3}$} & $\mathrm{~N}_{1}$ & $100.60 \mathrm{efg}$ & $24.00 \mathrm{~b}-\mathrm{e}$ & $12.80 \mathrm{abc}$ & $130.30 \mathrm{jkl}$ \\
\hline & $\mathrm{N}_{2}$ & 101.80def & $24.40 \mathrm{bcd}$ & $13.33 \mathrm{abc}$ & $133.20 \mathrm{ijk}$ \\
\hline & $\mathrm{N}_{3}$ & $104.80 \mathrm{bcd}$ & $24.73 a-d$ & $13.47 \mathrm{abc}$ & 133.60ij \\
\hline & $\mathrm{N}_{4}$ & $106.60 \mathrm{abc}$ & $25.47 \mathrm{abc}$ & $14.07 \mathrm{abc}$ & 136.10hi \\
\hline \multirow{4}{*}{$\mathrm{S}_{4}$} & $\mathrm{~N}_{1}$ & $94.82 \mathrm{~h}$ & $22.47 \mathrm{e}$ & $12.00 \mathrm{c}$ & $124.30 \mathrm{mn}$ \\
\hline & $\mathrm{N}_{2}$ & 98.33fgh & $23.47 \mathrm{de}$ & $13.00 \mathrm{abc}$ & $126.801 \mathrm{~m}$ \\
\hline & $\mathrm{N}_{3}$ & 99.93efg & $24.40 \mathrm{bcd}$ & $13.20 \mathrm{abc}$ & $127.401 \mathrm{~m}$ \\
\hline & $\mathrm{N}_{4}$ & $103.00 \mathrm{cde}$ & $24.93 \mathrm{a}-\mathrm{d}$ & $14.73 \mathrm{abc}$ & $129.60 \mathrm{kl}$ \\
\hline \multicolumn{2}{|c|}{ Level of Significance } & 0.05 & 0.05 & 0.05 & 0.05 \\
\hline \multicolumn{2}{|l|}{$L S D$} & 3.501 & 1.521 & 2.484 & 3.451 \\
\hline
\end{tabular}

$\mathrm{S}_{0}=$ No amendment, $\mathrm{S}_{1}=$ FYM $\left(5\right.$ tha $\left.^{1}\right)+$ Gypsum $14 \mathrm{kgha}^{-1}, \mathrm{~S}_{2}=\mathrm{FYM}\left(5 \mathrm{ha}^{1}\right)+$ Gypsum $210 \mathrm{kgha}^{-1}, \mathrm{~S}_{3}=$ Gypsum $210 \mathrm{kgha}^{-1}, \mathrm{~S}_{4}=$ FYM $\left(5 \mathrm{tha}^{1}\right), \mathrm{N}_{1}=50 \mathrm{~kg} \mathrm{Nha}^{-1}, \mathrm{~N}_{2}=75 \mathrm{~kg} \mathrm{Nha}^{-1}, \mathrm{~N}_{3}=100 \mathrm{~kg} \mathrm{Nha}^{-1}, \mathrm{~N}_{4}=125 \mathrm{~kg} \mathrm{Nha}^{-1}$ 


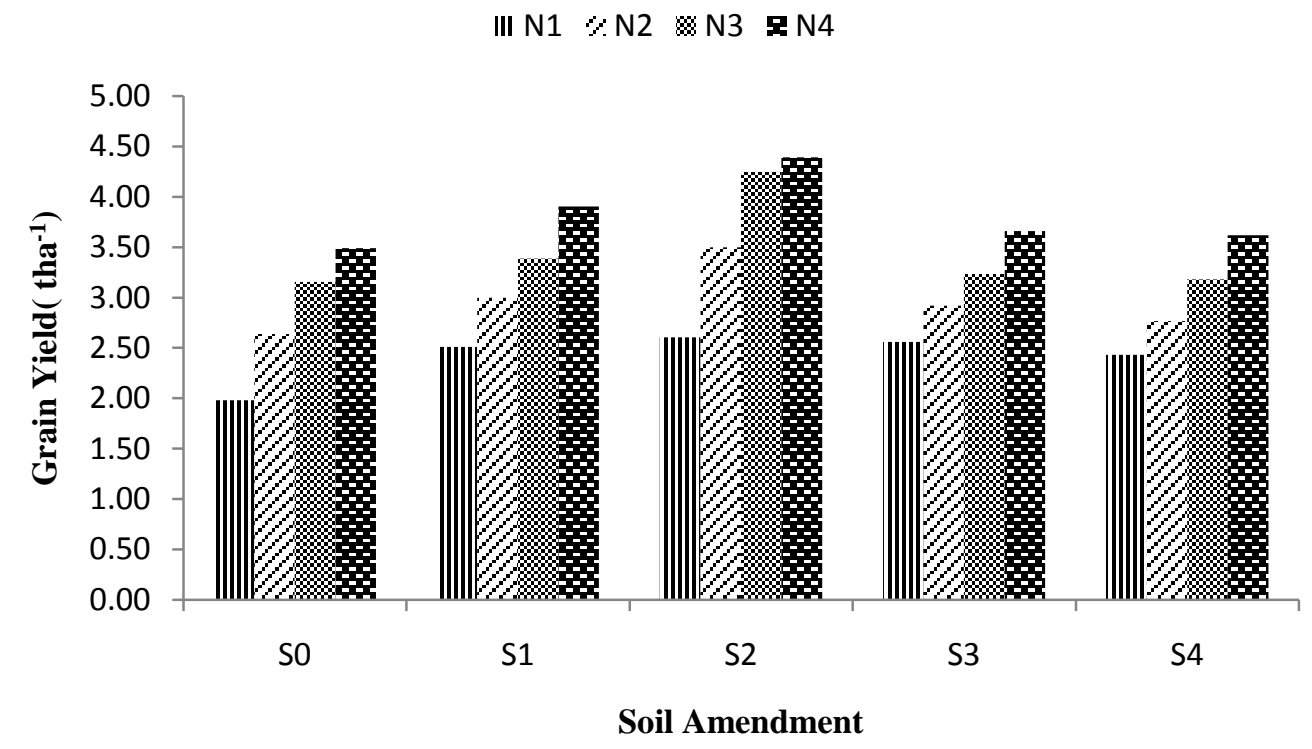

Figure 01. Interaction effect of FYM and Gypsum combinations and Nitrogen on Grain yield of rice (cv. Binadhan-8)

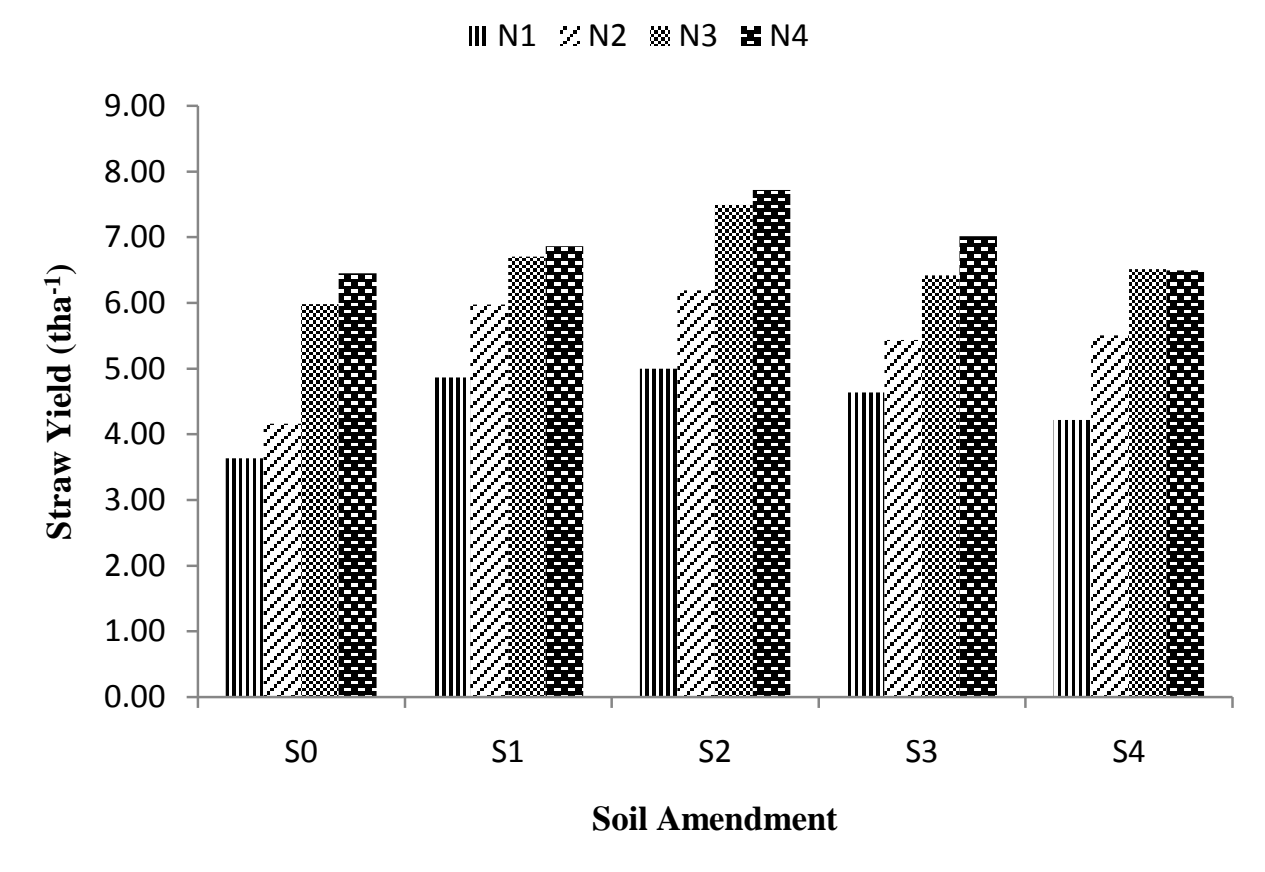

Figure 02. Interaction effect of FYM and Gypsum combinations and Nitrogen on Straw yield of rice (cv. Binadhan-8) 


\section{Conclusion}

FYM and Gypsum combinations along with different $\mathrm{N}$ levels have significant effect on growth and yield of rice in saline area of Satkhira district, Bangladesh. The mean effect of different FYM and Gypsum combinations the highest grain $\left(3.69 \mathrm{tha}^{-1}\right)$ and straw $\left(6.60 \mathrm{tha}^{-1}\right)$ yield were obtained where the plot received FYM@5 tha ${ }^{-1}$ with Gypsum $210 \mathrm{kgha}^{-1}$. Mean effect of different $\mathrm{N}$ levels, when the plant received $125 \mathrm{~kg} \mathrm{Nha}^{-1}$ then the maximum grain and straw yield of rice were observed as 3.81 and 6.91 tha $^{-}$ ${ }^{1}$, respectively. Due to the interaction effect of both FYM and Gypsum combinations and $\mathrm{N}$ levels, the maximum grain yield of rice was found as 4.39 tha $^{-1}$ under the treatment combination of $\mathrm{S}_{2} \mathrm{~N}_{4}$ where plot received FYM @ 5 tha $^{-1}$ with Gypsum $210 \mathrm{kgha}^{-1}$ combined with $125 \mathrm{~kg} \mathrm{Nha}^{-1}$.

\section{References}

Abro, S. A. \& Mahar, A. R. (2007). Reclamation of Saline-Sodic Soils under Rice-Wheat Crop Rotation. Pak. J. Bot., 39(7): 2595-2600.

Alim, M. A. (2012). Effect of Organic and Inorganic Sources and Doses of Nitrogen Fertilizer on the Yield of Boro Rice. J. Environ. Sci. \& Natural Resources, 5(1): 273- 282.

BARC. (2012). Fertilizer Recommendation Guide. Bangladesh Agricultural Research Council, Soils Pub. 45, Dhaka.

Black, C. A. (1965). Methods of Soil Analysis. Part I \& II. American Soc. of Argon. Inc. Pub. Madison, Wisconsin, USA.

Haque, S. A. (2006). Salinity Problems and Crop Production in Coastal Regions of Bangladesh. Pak. J. Bot., 38(5): 1359-1365.

Jackson, M. L. (1962). Soil Chemical analysis. Constable and Co. Ltd. London.

Joachim, H.J. R., Makoi, P. \&Ndakidemi, A. (2007). Reclamation of sodic soils in northern Tanzania, using locally available organic and inorganic resources. African J. Biotech.6(16), 1926-1931.

Khan, M. A. I., Ahmed, M.,Sutradhar, N. C., Alamand, Z. \&Haque, M. E.(2010). Effect of nitrogen application on green leaf production and seed quality of BRRIdhan 30. J. Agrofor. Environ. 3 (2):41.

Nelson, D. W. \&Sommers, L. E. (1982). Total carbon, organic carbon oan organic matter. In: Page, A. L. (Ed.), Methods of Soil Analysis Part 2. Monogr. No. 9. 2nd ed. ASA an SSSA, Madison, WI,pp. 539-580.

Olsen, S. R., Cole, C. V., Watanabe, F. S. \& Dean, L. A. (1954). Estimation of available phosphorus in soils by extraction with sodium bicarbonate. U. S. Dept. Agric. Circ. p.939.

Page, A. L., Miller, R. H. \& Keeney, D. R. (1982). Methods of Soil Analysis Part II. 2nded. Amer. Soc. of Argon. Inc. Pub. Madison, Wisconsin, USA.

Prapagar, K., Indraratne, S. P. \&Premanandharajah, P. (2012). Effect of FYM and Gypsum combinations on Reclamation of Saline-Sodic Soil. Tropical Agricultural Research, Vol. 23 (2): 168 -176.

Rasel, H. M., Hasan, M. R., Ahmed, B \&Miah, M. S. U. (2013). Investigation of soil and water salinity, its effect on crop production and adaptation strategy. Int. J. of Water Resources and Env. Engineering. Vol. 5(8), pp. 475-481.

Salahuddin, K. M., Chowhdury, S. H., Munira, S., Islam, M. M. \&Parvin, S. (2009). Response of Nitrogen and Plant Spacing of Transplanted AmanRice. Bangladesh J. Agril. Res. 34(2): 281.

Sinha, D. D., Singh, A. N. \& Singh, U. S. (2014). Site Suitability Analysis for Dissemination of SaltTolerant Rice Varieties in Southern Bangladesh. The International Archives of the Photogrammetry, Remote Sensing and Spatial Information Sciences, Vol. XL-8, pp. 964. 
SRDI (2010). Coastal Saline Soils of Bangladesh. Soil Resources Development Institute. Ministry of Agriculture, Dhaka, Bangladesh. pp. 96.

Suriyan, C., Yuthasak, P. \& Chalermpol K. (2011). Remediation of salt-affected soil by Gypsum and farmyard manure - Importance for the production of Jasmine rice. Aust. J. Crop. Sci.,5(4):458465.

UN-DSD (2000). Promoting sustainable agriculture and rural development, United Nations (UN), New York.

Villa-Castorena, M., Ulery, A. L., Catalan-Valencia, E. A., Remmenga, M. D., (2003). Salinity and nitrogen rate effects on the growth and yield of chilepepper plants. Soil Sci. Soc. Am. J. 67:17811789.

Zakir, A. M., Bajwa, B. S. \& S. M. Sjjad, (1997). Impact of Gypsum and farmyard manure on saline water irrigation at different growth stages and yield of rice. Current Agric. 22(1-2): 112-117.

Ziaul H. M. \& Zaber H. M. (2013). Impact of salinity on livelihood strategies of farmers. J. Soil Sci. Plant Nutr. vol.13(2), pp. 417-431.

\section{Citation for this article (APA Style):}

Haque, A. N. A., Haque, M. E., Hossain, M. E., Khan, M. K. \& Razzaque, A. H. M. (2015). Effect of Farm Yard Manure, Gypsum and Nitrogen on Growth and Yield of Rice in Saline Soil of Satkhira District, Bangladesh. Journal of Bioscience and Agriculture Research 03(02), 65-72.

Retrieved March 11, 2015 from http://www.journalbinet.com/jbar-volume-03-issue-01.html 